\title{
US-Panama Free Trade Agreement: What Is in It for Florida Agriculture? ${ }^{1}$
}

\author{
Edward A. Evans and Fredy H. Ballen²
}

\section{Introduction}

On October 12, 2011, four years after it was agreed upon by both parties, the United States government signed into law the reciprocal US-Panama Free Trade Agreement (FTA)/ Trade Promotion Agreement (TPA). The FTA provides US companies with better access to the Panamanian market and ensures that most US exports of consumer and industrial products to Panama will be accorded immediate duty-free privileges (other tariffs are scheduled to be phased out over a 20 -year period). US products receiving immediate duty-free access to the Panamanian market include information technology (IT); construction contracts; agricultural, medical, and scientific equipment; agrochemicals; agricultural products; and pharmaceuticals (Office of the US Trade Representative 2012). Other provisions of the FTA deal with the protection of intellectual and labor rights and a commitment to fair and open procurement of goods and services.

On the other side, the FTA will afford Panama producers increased market access to the United States, although the impact is likely to be limited because Panama already has substantial duty-free access to the United States under the Generalized System of Preferences (GSP) and the Caribbean Basin Economic Recovery Act (CBERA). Panama is one of the fastest-growing markets in Latin America and a relatively important trading partner for the United States. Panama's total imports increased from $\$ 8.10$ billion in 2000 to $\$ 19.8$ billion in 2010 , at an annual rate of 14.44 percent.

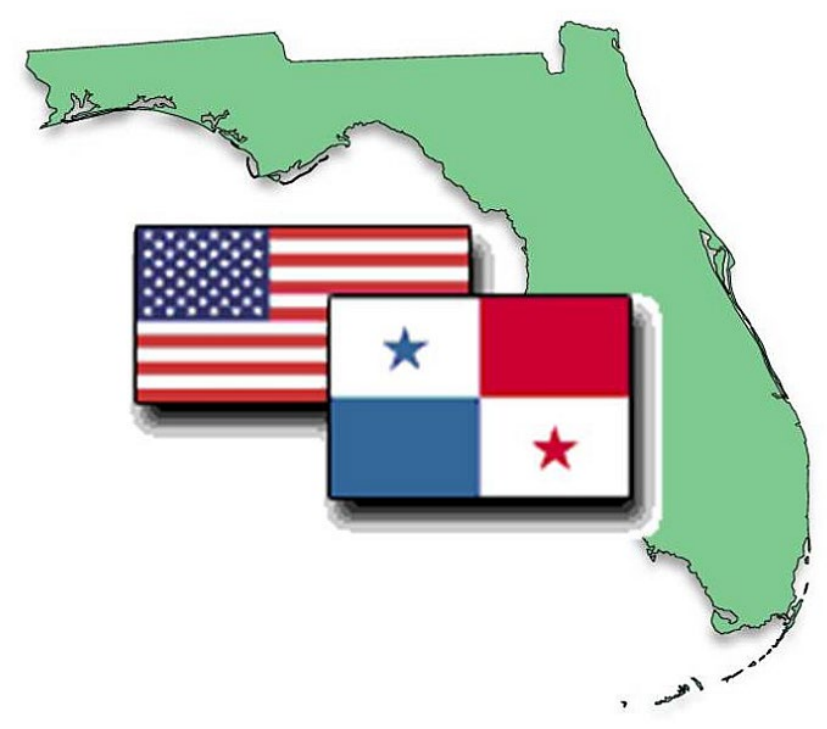

In 2010, US exports to Panama totaled $\$ 3.04$ billion, or 15.35 percent of the total imports to Panama that year. In comparison, Panamanian exports to the United States increased from $\$ 7.8$ billion in 2000 to $\$ 18.4$ billion in 2010 , growing at an annual rate of 13.58 percent. In 2010, Panamanian exports to the United States reached $\$ 145$ million, or 0.78 percent of the total exports value.

The bulk of trade between the United States and Panama is non-agricultural, with agricultural commodities accounting for only 15.62 percent of the total two-way trade in 2010 . US agricultural exports to Panama grew by 158.82 percent,

1. This is EDIS document FE932, a publication of the Department of Food and Resource Economics, Florida Cooperative Extension Service, Institute of Food and Agricultural Sciences, University of Florida, Gainesville, FL. Published May 2013. Please visit the EDIS website at http://edis.ifas.ufl.edu

2. Edward A. Evans, associate professor, Department of Food and Resource Economics, University of Florida, Tropical Research and Education Center, Homestead, FL, and Fredy H. Ballen, economic analysis coordinator II, University of Florida, Tropical Research and Education Center, Homestead, FL. 
from $\$ 171.81$ million in 2000 to $\$ 444.69$ million in 2010 , while US agricultural imports from Panama grew by 50.66 percent, from $\$ 35.41$ million in 2000 to $\$ 53.36$ million in 2010. US agricultural exports to Panama are comprised mainly of cereals and miscellaneous edible preparations, while imports consist mainly of sugar and tropical products. In 2010, Panama ranked 65th in destination for US agricultural imports, and 43rd in destination for US agricultural exports (USDA/FAS 2012c).

US agricultural trade with Panama can be considered complementary and non-competitive, given the growing importance of agricultural exports to the economy of Florida and the closer similarity between agricultural commodities produced by Panama and the state of Florida compared to commodities produced in most other parts of the United States. This article examines in further detail the main elements of the US-Panama FTA as they relate to trade in agricultural commodities and the implications for Florida specialty crop producers. In 2010, 19.34 percent ( $\$ 2.93$ billion) of Florida's gross farm cash income came from export revenues. Export sales are an important source of income to the Florida farm economy, supporting about 12,600 jobs (USDA/FAS 2012b). Overseas sales of fresh fruits and vegetables account for the bulk of the share (42.6\%). In 2011, Florida agricultural exports to Panama totaled $\$ 88.76$ million, making the country the eighth most important destination for Florida agricultural exports and the most important market for Florida agricultural products in Central America (USDA/FAS 2012c).

\section{Socioeconomic Indicators of the}

\section{Panamanian Market}

Panama is a services-oriented economy (e.g., banking, commerce, tourism, and access to the Panama Canal), with the service sector accounting for 80 percent of the GDP. The FTA with Panama offers US companies access to a market of about 3.5 million consumers. Despite the relatively small consumer base, Panama's economy has experienced significant growth since 2000. Overall, economic indicators, such as poverty level, total GDP, per-capita GDP, unemployment rate, inflation rate, and trade balance, improved considerably during the period 2000-2010 as a result of economic policies to promote trade liberalization and efforts to attract foreign investment (Table 1).

Panama's GDP has more than doubled, from $\$ 11.60$ billion in 2000 to $\$ 26.70$ billion in 2010 . Personal income, measured as per-capita GDP, has increased by 124 percent, from $\$ 3,391$ in 2000 to $\$ 7,614$ in 2010 . The unemployment rate has fallen by half, from 13.5 percent to 6.5 percent, over the same period. The agricultural labor force increased slightly from 17 percent in 2000 to 19.3 percent in 2005. Historically, the inflation rate in Panama has been low; in 2010, it was only 3.5 percent. Panama is actively involved in international trade; the country has increased its exports of goods and services by 136 percent, from $\$ 7.8$ billion in 2000 to $\$ 18.4$ billion in 2010 . Growth in exports has been a key factor in reducing the trade gap. Poverty reduction is an ongoing concern, with significant progress being made, whereby those living below the poverty line fell from 37 percent in 2000 to 28.6 percent in 2010 (World Bank 2012).

\section{Main Elements of US-Panama FTA}

The main elements of the US-Panama FTA as it relates to agricultural trade revolve around market access, agricultural export subsidies, safeguards, the sugar compensation mechanism, and sanitary and phytosanitary measures, all of which are explained below and summarized in Table 2 .

\section{Market Access}

Market access refers to the tariff and non-tariff measures negotiated for the entry of specific goods into the respective market. Liberalization of Panama's agricultural imports market will occur under the FTA through tariff reductions and Tariff Rate Quotas (TRQs).

Tariff elimination for agricultural products ranges from immediate duty-free access to a maximum phase-out period of 20 years. Tariffs on 68 percent of Panama's agricultural tariff lines, which account for more than half of the current US trade by value, will be eliminated immediately (Office of the US Trade Representative 2012). Most of the tariffs are scheduled to be phased out over a 15 -year period, with some products, such as rough and milled rice, taking up to 20 years (Office of the US Trade Representative 2012). Tariffs will be reduced in equal amounts each year during the phase-out period, with the first tariff cut becoming effective the date the FTA enters into force. Sensitive products will be subject to a special treatment. After an initial grace period, tariff cuts will be scheduled annually.

A few sensitive products, such as beef, chicken leg quarters, pork, corn, rice, and dairy products, will be accorded immediate duty-free access through TRQs. A TRQ is a trade policy tool that protects a domestically produced product from competitive imports. A TRQ is the combination of tariffs and quotas (two policy instruments) to restrict imports. While products imported under the quota portion of the TRQ enter duty free, products imported above the quota threshold are subject to tariff. Quotas are scheduled 
for annual increases during the phase-out period. As part of the agreement, agricultural products with longer tariff elimination periods will have immediate duty-free access through the quota portion of the respective TRQ. Most of the quota portion of the TRQs will be filled on a first-come, first-served basis. The agreement also includes special disciplines for Panamanian TRQs that will be subject to auctions or historical licenses, and a prohibition on the use of domestic purchase requirements.

\section{Safeguards}

As with most FTAs, the US-Panama Free Trade Agreement has general trade remedies in the form of safeguards. A safeguard is a tool used to allow for temporary increases in import protection beyond the levels negotiated in a staged schedule of tariff reductions within the FTA. A country may invoke the safeguard in order to temporarily restrict the importation of a commodity that would cause serious damage to the domestic producers of that particular commodity. After import quantities exceed predetermined trigger levels, the importing country may invoke the use of a safeguard. Invoking the safeguard temporarily restrains imports of the protected product as the importing country exercises the right granted by the safeguard to temporarily raise tariffs on that product. The US-Panama FTA includes the use of agricultural safeguards for certain products, allowing temporary tariff increases if import quantities exceed agreed-upon trigger levels. Once tariff protection for a particular product has been phased out, the use of a safeguard is no longer allowed.

\section{Export Subsidies}

Export subsidies are used to encourage export activity; they are considered a negative tax (i.e., a payment to the firm by the government when a particular product is exported). Under the agreement, both parties share the objective of eliminating export subsidies. Neither party may introduce or maintain any export subsidy on any agricultural product shipped into the other party's territory unless the export subsidy is used to compete with third-party export subsidies.

\section{Sugar Compensation Mechanism}

At any time, the United States may, at its option, apply a mechanism that results in compensation to Panama's exporters of sugar goods in lieu of according duty-free treatment to some or all of the duty-free quantities of sugar goods established for Panama. The compensation shall be equivalent to the estimated economic rents that Panama's exporters would have obtained on exports to the United
States of any such amounts of sugar goods and shall be provided within 30 days after the United States exercises this option. The United States shall notify Panama at least 90 days before it exercises this option and, on request, shall enter into consultations with Panama regarding application of the mechanism.

\section{Sanitary and Phytosanitary Measures (SPS) and Technical Standards}

Sanitary and phytosanitary measures (SPS) are policies to ensure food safety. Phytosanitary measures specifically protect against infectious diseases of plants. The agreement on SPS and technical standards seeks to address many SPS and other regulatory issues related to trade in raw/fresh and processed products. Panama recognizes the equivalence of the US food safety inspection system, ending its requirements for its own plant-by-plant and/or shipmentby-shipment inspections. Panama re-opened its market to US exports of beef and chicken based on international SPS standards. Import documentation requirements, including Panama's product registration system for processed foods and for US agricultural products, have been simplified.

\section{Analysis of US-Panama FTA for Florida Agricultural Producers}

\section{Panamanian Agriculture}

Panamanian imports and exports to the United States of selected agricultural commodities during 2007-2011 are shown in Table 3. If the net import column has a positive value, it indicates that the country is a net importer of the specific commodity group; a negative value in the net import column for a given commodity group indicates that the country is a net exporter of that commodity group. Considering only the five commodity categories previously selected, Panama was a net importer of US agricultural products during 2007-2011, with an average trade deficit of \$41.65 million.

Panamanian imports of US vegetable, fruit, and nut preparations averaged $\$ 20.73$ million, while Panamanian exports of these products to the United States averaged $\$ 0.30$ million during the reporting period, resulting in a trade deficit of $\$ 20.43$ million. The average value of US meat and edible meat imported to Panama was $\$ 18.97$ million a year; Panamanian meat product exports during the time period reported was $\$ 0$, resulting in a trade deficit of $\$ 18.97$ million for the meat and edible meat group. 
In the case of edible fruits and nuts, Panamanian imports from the United States averaged \$15.41 million a year, while Panamanian exports to the United States averaged \$15.24 million a year during the time reported, resulting in a slight trade deficit of about $\$ 0.17$ million (Table 4). Panama averaged $\$ 4.15$ million a year in imports of US edible vegetables, while Panamanian exports of these products to the United States averaged $\$ 2.44$ million, resulting in a trade deficit of $\$ 1.71$ million. Panamanian imports of US live trees and other plants averaged $\$ 0.38$ million, while Panamanian exports to the United States of these products averaged only $\$ 20,000$, resulting in a trade deficit of $\$ 0.36$ million for this category.

The average five-year value of Panama's world and US imports of the selected commodities are shown in Table 4. It can be seen that the United States supplied 29.53 percent of Panama's vegetable, fruit, and nut preparations during 2007-2011. In the case of meat and edible meat, it is worth mentioning that the United States supplies more than half of Panama's import needs despite this commodity group being subject to high tariffs of up to 260 percent, as is the case for some poultry products. Clearly, the United States has a competitive advantage in this area, and with the FTA the United States could increase its market share even more. During 2007-2011, the United States supplied 53.85 percent, 19.52 percent, and 7.43 percent of the total Panamanian imports of edible fruits and nuts, edible vegetables, and live trees and other plants, respectively.

The main agricultural exports from Panama to the United States are sugar and sugar confectionaries, edible fruits and nuts, and coffee, respectively. During 2007-2011, the average Panama export value for sugar and sugar confectionaries, edible fruits and nuts, and coffee were $\$ 21.73$ million, $\$ 15.24$ million, and \$10.24 million, respectively. During this period, Panamanian exports of raw sugarcane to the United States increased at an annual rate of 7.31 percent, from $\$ 14.65$ million in 2007 to $\$ 38.10$ million in 2011 . The main fruits exported from Panama to the United States are, in order of most to least exported, bananas, pineapples, watermelons, and muskmelons. During 2007-2011, banana exports to the United States increased at an annual rate of 16.45 percent, from $\$ 0.15$ million in 2007 to $\$ 10.43$ million in 2011, and pineapple exports increased 36.04 percent, from $\$ 5.16$ million in 2007 to $\$ 7.03$ million in 2011 . In contrast, during this period, watermelon exports to the United States decreased 40.09 percent, from $\$ 0.64$ million in 2007 to $\$ 0.38$ million in 2011 , and muskmelon exports decreased 98.74 percent, from $\$ 5.67$ million in 2007 to $\$ 0.07$ million in 2011. Panama exports of unroasted coffee have decreased by 38.08 percent, from $\$ 13.20$ million in 2007 to $\$ 8.17$ million in 2011(USDA/NASS 2011).

It is estimated that US exporters of these selected commodities might increase their share of exports to the Panamanian market due to the elimination and/or gradual reduction of import duties resulting from the FTA. In the next section we will take a deeper look to see which commodities may represent the best option for Florida growers interested in exporting to Panama.

\section{Florida Agriculture}

Cash receipts from Florida agricultural products reached $\$ 7.81$ billion in 2010, an increase of $\$ 641$ million over receipts in 2009 (USDA/NASS 2011). Crop production is the main agricultural activity in Florida, accounting for 82.72 percent of total cash receipts, with livestock and livestock products accounting for the balance. With regard to major crop categories, the total cash income is shared among fruits and nuts (25.38\%), vegetables and melons (24.87\%), greenhouse and nursery (22.43\%), citrus (19.61\%), and field crops (10.02\%).

Florida's leading cash receipts by commodity for the year 2010 are shown in Table 5. Cash receipts for the 23 leading commodities in 2010 totaled $\$ 7.33$ billion. The top five agricultural commodities and their respective share of the total value in 2010 were greenhouse/nursery $(22.36 \%)$, oranges $(16.00 \%)$, tomatoes $(8.08 \%)$, sugarcane $(6.96 \%)$, and cattle/calves $(6.44 \%)$, or 59.84 percent of the total cash receipts from agricultural products. In terms of value, Florida is the leading producer of oranges, sugarcane, watermelons, grapefruit, snap beans, cucumbers, and squashes in the United States. Florida ranks second nationally in the production of greenhouse/nursery products, tomatoes, strawberries, bell peppers, blueberries, and tangerines.

Table 6 shows the top five leading Florida agricultural exports to the world during 2007-2011. The five leading Florida agricultural exports to the world and their respective shares of the total value were edible fruits and nuts (14.21\%); vegetable, fruit, and nut preparations (13.73\%); meat and edible meat (12.67\%); edible vegetables (9.61\%); and live trees and other plants (3.75\%). The commodity categories illustrated in Table 6 represent about 54 percent of the total value of Florida agricultural exports during 2007-2011; Florida agricultural exports increased 42 percent, from $\$ 2.53$ billion in 2007 to $\$ 3.59$ billion in 2011 . During this period, Florida exports of edible fruits and nuts increased at an average annual rate of 2.80 percent, from \$396.25 million in 2007 to $\$ 440.75$ million in 2011 . 
In order of most to least exported, the main products within this category are citrus fruits, muskmelons and watermelons, strawberries, and cranberries. Florida exports of vegetable, fruit, and nut preparations increased at an average annual rate of 9.60 percent, from $\$ 384.93$ million in 2007 to $\$ 532.78$ million in 2011 . The main exports within this category are, in order of most to least exported, fruit and vegetable juices, fruit and nut preparations, and vegetable preparations. With the highest growth rate among the commodities selected, Florida exports of meats and edible meats increased at an average annual rate of 26.04 percent, from $\$ 266.86$ million in 2007 to $\$ 544.85$ million in 2011. The main products exported within this category, in order of most to least exported, include poultry meat, bovine meat, and swine meat. Florida exports of edible vegetables increased at an average annual rate of 0.88 percent, from $\$ 287.74$ million in 2007 to $\$ 297.90$ million in 2011. The main edible vegetables exported are, in order of most to least exported, fresh tomatoes, fresh peppers, and leguminous vegetables. In contrast, Florida exports of live trees and other plants decreased at an annual rate of -1.70 percent, from \$113.44 million in 2007 to $\$ 105.69$ million in 2011 . The main products exported within this category, in order of most to least exported, include live plants, dried cut flowers, foliage, and bulbs.

\section{Implications of the US-Panama FTA for Florida Agricultural Producers}

Based on the assumption that the five categories in Table 6 (Florida's main agricultural exports) identify the main commodities in which Florida growers may have a competitive advantage, the following analysis explores the potential export opportunities for Florida producers resulting from the US-Panama FTA. Table 7 shows the average export value (2007-2011) of the selected products that might enhance Florida's export revenues immediately after the US-Panama FTA goes into effect. Table 8 summarizes the pre-FTA and post-FTA market access conditions for the selected products within each major commodity group.

Among the edible fruits, fresh strawberries ranks as the third most important fruit Florida export after grapefruit and cranberries. Florida total exports of fresh strawberries averaged $\$ 45$ million during 2007-2011. Less than 1 percent of the Florida strawberry exports reached the Panamanian market. In contrast, during this period, Panama strawberry imports increased 51.87 percent, from $\$ 0.41$ million in 2007 to $\$ 0.63$ million in 2011 (UN/Comtrade 2012).Oranges rank as the second most important
Florida export after grapefruit in the citrus fruit category, and as eighth among all fresh fruits. Total exports of Florida oranges averaged \$12.75 million from 2007 to 2011 . While Florida orange exports to Panama have been marginal, reaching only $\$ 43,000$ in 2011, Panama's orange imports have grown over 240 percent, from $\$ 0.18$ million in 2007 to $\$ 0.64$ million in 2011 (UN/Comtrade 2012). During this same period, Florida's global fresh grape exports were about $\$ 12.70$ million, with less than 1 percent destined for Panama, where imports of this fruit increased 47 percent, from $\$ 6.86$ million in 2007 to $\$ 10.09$ million in 2011 (UN/ Comtrade 2012). Between 2007 and 2011, Florida's global walnut exports averaged $\$ 1.21$ million per year, with exports to Panama fluctuating from a high of $\$ 0.23$ million in 2008 to a low of $\$ 0.12$ million in 2009 . In contrast, Panamanian walnut imports increased from $\$ 0.67$ million in 2007 to $\$ 1.15$ million in 2011 (UN/Comtrade 2012). Frozen strawberry exports from Florida on the global market averaged $\$ 0.38$ million during 2007-2011, with 28 percent destined for Panama. During the time period under analysis, Panamanian total imports of this product increased 281.63 percent, from $\$ 0.16$ million in 2007 to $\$ 0.62$ million in 2011. Florida exports of fresh and frozen strawberries and fresh oranges to Panama might present the best opportunities within the edible fruits category, given that Panama's imports of these fruits have followed an upward trend in recent years. Florida exports of these fruits will be more competitively priced because oranges will immediately enter the Panamanian market duty free, and the 15 percent tariff for fresh and frozen strawberries will be removed in 10 equal annual stages as a result of the agreement (Table 8). Despite the size of the import market for strawberries and oranges, it is important to note that higher per capita income is correlated with a higher consumption of fresh fruits. Export opportunities in the Panamanian market for walnuts and fresh grapes will depend on other factors because walnuts and fresh grapes entered duty free before the FTA (Table 8).

The next commodity group in importance to Florida is vegetable, fruit, and nut preparations. The products with the best prospects to increase Florida's export share for this particular segment in the Panamanian market are, in order of importance, preparations of nuts, seeds, and potatoes. Florida's global nut preparation exports averaged $\$ 12.20$ million a year during 2007-2011; Florida exports of nut and seed preparations to Panama increased 86.23 percent, from $\$ 0.66$ million in 2007 to $\$ 1.23$ million in 2011. During the same period, Panama's total imports of nut and seed preparations more than doubled, from $\$ 1.28$ million to $\$ 2.75$ million (UN/Comtrade 2012). Total exports of prepared 
potatoes from Florida averaged $\$ 4.22$ million a year during 2007-2011. Florida exports to Panama of prepared potatoes decreased, from $\$ 0.41$ million in 2007 to $\$ 0.26$ million in 2011, while Panamanian imports of this product increased, from \$10.61 million in 2007 to \$15.45 million in 2011 (UN/ Comtrade 2012). Florida's preparations of nuts, seeds, and potatoes are the products most likely to increase export revenues from Panama in this category once the USPanama FTA goes into force. Prepared potatoes are subject to an import duty of 20 percent; as a result of the agreement, tariffs for frozen French fries will be removed in 5 years through the implementation of a TRQ, and tariffs on other prepared potato products will be eliminated within 10 years through 10 equal annual stages (Table 8). Market access for Florida exports of nut and seed preparations will be as follows: toasted almonds and buttered almonds will not benefit from the FTA tariff reduction because these products already enter the Panamanian market duty free, and peanut mixes will no longer be subject to a 15 percent tariff (Table 8).

Poultry meat, bovine meat, and frozen swine cuts are, in that order, the leading Florida exports within the meat and edible meat offal category. During 2007-2011, Florida's exports to Panama in this category increased as follows: poultry fowl increased from $\$ 0.33$ million in 2007 to $\$ 2.53$ million in 2011; frozen bovine boneless meat increased from $\$ 0.12$ million in 2007 to $\$ 2.46$ million in 2011 ; and frozen swine cuts increased from $\$ 8,000$ in 2007 to $\$ 0.54$ million in 2011. During the same period, Panama's total imports in this category increased as follows: poultry fowl increased 332.84 percent, from $\$ 1.32$ million to $\$ 5.72$ million; frozen bovine boneless meat increased 358.52 percent, from $\$ 0.68$ million to $\$ 3.15$ million; and frozen swine cuts increased 188.46 percent, from $\$ 0.78$ million to $\$ 2.25$ million (UN/Comtrade 2012). Florida exporters of poultry meat, bovine meat, and swine meat could increase their share of the Panamanian market in the future because the FTA provides better market access conditions for these products. In the case of poultry fowl, duty-free access is granted under a TRQ, starting at 660 metric tonnes ( $t$ ) for chicken leg quarters, with tariffs phased out over 18 years (Table 8). The FTA stipulates duty-free access for Prime and Choice beef cuts; tariffs for standard quality beef will be eliminated in 15 years (Table 8). Fresh and frozen pork cuts will access the Panamanian market duty free through a 1,600 t TRQ, growing at a compounded annual rate of 6 percent or higher. Standard beef and some swine meat products will be subject to a safeguard (Table 8). Despite the seemingly low stipulated TRQs, it is worth mentioning that the overall price competitiveness for US and Florida exports of edible meats will improve based on Panama's varying pre-FTA applied tariffs: $0-260$ percent for poultry meat, $60-70$ percent for swine meat, and $15-30$ percent for bovine meat.

The next Florida agricultural export category in importance is edible vegetables. The products within this category with the best chance of increasing Florida export revenues from Panama are dried kidney beans and frozen sweet corn. During 2007-2011, Panama accounted for less than 1 percent of Florida exports of dried kidney beans; Panamanian total imports of this product increased 177.04 percent, from \$1.09 million in 2007 to $\$ 3.04$ million in 2011 (UN/ Comtrade 2012). Total imports of Florida frozen sweet corn to Panama doubled from $\$ 0.25$ million to $\$ 0.52$ million during 2007-2011 (UN/Comtrade 2012). The FTA probably will make Florida exports of these products to Panama more competitive as they begin to enter the Panamanian market duty free. (Table 8).

Finally, the last commodity group considered in the present report is live trees and other plants. From 2007 to 2011, total exports of live plants from Florida averaged $\$ 38.62$ million, with less than 1 percent destined for Panama. Even though live plants imported by Panama during 2007-2011 increased 1,063.88 percent, from $\$ 0.10$ million in 2007 to $\$ 1.18$ million in 2011 (UN/Comtrade 2012), the price competitiveness of Florida exports of live plants to Panama will not improve significantly because these products already access the Panamanian market duty free (Table 8).

\section{Concluding Remarks}

The US-Panama FTA constitutes a significant step toward trade openness; removing trade barriers will facilitate the bilateral flow of goods and services. As a result of the agreement, US agricultural products will compete on the same terms with exports from other countries in the Panamanian market.

While tariff elimination/gradual reduction will make Florida agricultural exports to Panama more competitive, major gains in Florida's share of the Panamanian agricultural imports market will depend upon price competitiveness with other suppliers, including other US states. Of special interest to Florida exporters are energy prices and macroeconomic conditions that may impact Florida's competitiveness in the global market. Transportation costs will have an important effect on final export prices as Florida competes with Panama's neighboring countries. US macroeconomic conditions have implications for US and Florida exports as well; a weak dollar will make US exports cheaper and more 
competitive with exports from other countries, and vice versa. On the bright side, foreign exchange risk is not an issue in Panama because the balboa and the US dollar are the official currencies; the balboa is tied to the US dollar at an exchange rate of 1:1 and circulates alongside the US dollar.

Florida producers are likely to benefit because they maintain a trade surplus for many of the commodities selected. The openness of the Panamanian agricultural imports market represents an opportunity to increase Florida's agricultural exports revenue. Opportunities for other Florida agricultural exports also exist but are not discussed in this report, which is focused on export-ready products in a growing import market.

The Florida agricultural products with the best prospects of increasing Florida's export revenue from the FTA with Panama are poultry meat, bovine meat, swine meat, fresh and frozen strawberries, fresh oranges, prepared tomatoes, dried beans, and frozen sweet corn. Because Florida exports of shelled walnuts, fresh grapes, prepared nuts, and live plants already access the Panamanian market duty free, no major gains in export price competitiveness for these products will result from the agreement.

Under the current terms, the US-Panama FTA does not seem to pose any threat to the Florida agricultural industry. With the exception of raw sugarcane and watermelons, Panama's main agricultural exports to the United States are complementary and non-competitive (bananas, pineapple, and coffee). Panamanian exports of raw sugarcane to the United States are subject to the Sugar Compensation Mechanism, which protects the US sugar industry. Panamanian exports of watermelons to the United States have decreased substantially because of a downward trend in Panama's domestic production of this fruit. The Florida citrus industry will not be impacted by the FTA; Panamanian citrus production is mainly for domestic consumption. The FTA will not have a significant impact on US imports of edible fruits and nuts and edible vegetables from Panama because most of the Panamanian agricultural exports to the United States already have duty-free access due to the Caribbean Basin Initiative.

As has been the case in other trade agreements, some sectors will have to make adjustments to remain competitive. Finally, it is important to mention that trade patterns may change over time, and former importers may become exporters with the right combination of research, investment, and technology.

\section{References}

Office of the US Trade Representative. 2012. US-

Panama Free Trade Agreement. http://www.ustr.gov/ trade-agreements/free-trade-agreements/panama-tpa.

UN/Comtrade. 2012. Commodity Trade Statistics Database. United Nations, New York. http://comtrade.un.org/db/ default.aspx.

US Census Bureau, Foreign Trade. Trade in Goods with Panama. http://www.census.gov/foreign-trade/balance/ c2250.html.

\section{USDA/FAS. 2012a. US-Panama Trade Promotion} Agreement Fact Sheets A. United States Department of Agriculture, Foreign Agricultural Service, Washington, D.C. http://www.fas.usda.gov/info/factsheets/Panama/ Florida_PTPA_September\%202011.pdf.

USDA/FAS. 2012b. Global Agriculture Trade System B. United States Department of Agriculture, Foreign Agricultural Service, Washington, D.C. http://www.fas.usda.gov/ gats/default.aspx.

USDA/FAS 2012c. US-Panama Trade Promotion Agreement. United States Department of Agriculture, Foreign Agricultural Service, Washington, D.C. http://www.fas. usda.gov/info/factsheets/Panama/Panama\%20TPA\%20 Detailed\%20Fact\%20Sheet\%2008-12.pdf.

USDA/NASS. 2011. Farm Cash Receipts and Expenditures. United States Department of Agriculture, National Agriculture Statistics Service, Washington, D.C. http://www. nass.usda.gov/Statistics_by_State/Florida/Publications/ Economics/fcr\&e/fcrexp11.pdf.

World Bank. 2012. World Databank: World Development Indicators. http://databank.worldbank. org/data/views/variableselection/selectvariables. aspx? source $=$ world-development-indicators.

WTO. 2012. Tariff Download Facility. World Trade Organization, Geneva, Switzerland. http://tariffdata.wto.org/ ReportersAndProducts.aspx. 
Table 1. Socioeconomic indicators of Panama, 2000-2010

\begin{tabular}{|lccc|}
\hline Indicator & $\mathbf{2 0 0 0}$ & $\mathbf{2 0 0 5}$ & $\mathbf{2 0 1 0}$ \\
\hline Population (millions) & 2.8 & 3.03 & 15.4 \\
GDP (US\$ billions) & 11.6 & 4,775 & 26.7 \\
Per-capita GDP & 3,391 & 9.8 & 7,614 \\
Unemployment rate & 13.5 & 19.3 & -3.5 \\
Agricultural labor force & 17 & 3.2 & 3.5 \\
Inflation rate (\%) & 1.5 & 10.6 & 18.4 \\
Exports (US\$ billions) & 7.8 & 10.7 & 37 \\
Imports (US\$ billions) & 8.1 & 37 & 28.6 \\
Poverty rate (\%) & & & \\
\hline Source: World Bank (2012). & & 3.8 & \\
\hline
\end{tabular}

Table 2. Summary of the main element of the US-Panama Free Trade Agreement

\begin{tabular}{|c|c|c|c|c|}
\hline Category & \multicolumn{4}{|c|}{ Elements of Free Trade Agreement } \\
\hline Market Access & \multicolumn{4}{|c|}{$\begin{array}{l}\text { Tariff elimination for US agricultural products landing on the Panamanian market will range from immediate } \\
\text { duty-free access to a phase-out period of no more than } 20 \text { years. } \\
\text { Sensitive products will access the Panamanian market duty free through Tariff Rate Quotas (TRQs). }\end{array}$} \\
\hline Safeguards & \multicolumn{4}{|c|}{$\begin{array}{l}\text { The agreement includes the right to involke a safeguard after import quantities for certain products surpass } \\
\text { predetermined trigger levels. }\end{array}$} \\
\hline Agricultural Export Subsidies & \multicolumn{4}{|c|}{$\begin{array}{l}\text { The United States and Panama agree on eliminating export subsidies, which will be allowed only to compete } \\
\text { with third-party export subsidies. }\end{array}$} \\
\hline $\begin{array}{l}\text { Sugar Compensation } \\
\text { Mechanism }\end{array}$ & \multicolumn{4}{|c|}{$\begin{array}{l}\text { US sugar imports from Panama are subject to a specific clause under which the United States can choose to } \\
\text { execute a mechanism to compensate Panama's sugar exporters regardless of whether or not the duty-free } \\
\text { quotas allowed to Panama have been fulfilled. }\end{array}$} \\
\hline $\begin{array}{l}\text { Sanitary and Phytosanitary } \\
\text { Measures }\end{array}$ & \multicolumn{4}{|c|}{$\begin{array}{l}\text { US food exports to Panama are no longer required to meet plant-by-plant or shipment-by-shipment sanitary } \\
\text { requirements because Panama recognizes the US food safety inspection system. }\end{array}$} \\
\hline \multicolumn{5}{|c|}{ Source: Office of the US Trade Representative (2012). } \\
\hline \multicolumn{2}{|l|}{ Product } & Imports from US & Exports to US & Net Imports \\
\hline \multicolumn{2}{|c|}{ Vegetable, fruit, or nut preparations } & 20,734 & 303 & 20,431 \\
\hline \multicolumn{2}{|l|}{ Meat and edible meat offal } & 18,971 & - & 18,971 \\
\hline \multicolumn{2}{|l|}{ Edible fruits and nuts } & 15,417 & 15,240 & 177 \\
\hline \multicolumn{2}{|l|}{ Edible vegetables } & 4,155 & 2,440 & 1,715 \\
\hline \multicolumn{2}{|l|}{ Live trees and other plants } & 385 & 20 & 365 \\
\hline \multicolumn{5}{|l|}{ Source: USDA/FAS (2012a). } \\
\hline
\end{tabular}

Table 4. Panama agricultural imports from the world and the United States 2007-2011 (USD 1,000s)

\begin{tabular}{|c|c|c|c|}
\hline Product & Imports from World & Imports from US & US \% \\
\hline Vegetable, fruit, or nut preparations & 70,210 & 20,734 & 29.53 \\
\hline Meat and edible meat offal & 34,801 & 18,971 & 54.51 \\
\hline Edible fruits and nuts & 28,632 & 15,417 & 53.85 \\
\hline Edible vegetables & 21,285 & 4,155 & 19.52 \\
\hline Live trees and other plants & 5,184 & 385 & 7.43 \\
\hline
\end{tabular}


Table 5. Florida's leading cash receipts by commodity, 2010 (USD 1,000s)

\begin{tabular}{|c|c|c|c|}
\hline Commodity & $\begin{array}{l}\text { Florida Receipts } \\
\qquad(\$ 1,000 s)\end{array}$ & $\begin{array}{c}\text { Share of Receipts } \\
\text { (\%) }\end{array}$ & $\begin{array}{c}\text { Cumulative Share } \\
\text { (\%) }\end{array}$ \\
\hline Greenhouse/nursery & $1,745,219$ & 22.36 & 22.36 \\
\hline Oranges & $1,248,875$ & 16.00 & 38.36 \\
\hline Tomatoes, fresh & 630,750 & 8.08 & 46.44 \\
\hline Sugarcane & 542,951 & 6.96 & 53.40 \\
\hline Cattle/calves & 502,456 & 6.44 & 59.83 \\
\hline Dairy products & 439,047 & 5.62 & 65.46 \\
\hline Strawberries & 362,032 & 4.64 & 70.10 \\
\hline Peppers, green & 295,555 & 3.79 & 73.88 \\
\hline Grapefruit & 204,829 & 2.62 & 76.51 \\
\hline Sweet corn & 189,197 & 2.42 & 78.93 \\
\hline Broilers & 151,493 & 1.94 & 80.87 \\
\hline Eggs & 150,746 & 1.93 & 82.80 \\
\hline Snap beans, fresh & 135,047 & 1.73 & 84.53 \\
\hline Potatoes & 128,509 & 1.65 & 86.18 \\
\hline Watermelons & 112,545 & 1.44 & 87.62 \\
\hline Peanuts & 89,606 & 1.15 & 88.77 \\
\hline Cucumbers & 88,543 & 1.13 & 89.90 \\
\hline Cabbage, fresh & 70,131 & 0.90 & 90.80 \\
\hline Tangerines & 65,272 & 0.84 & 91.64 \\
\hline Squash & 56,784 & 0.73 & 92.37 \\
\hline Cotton & 49,478 & 0.63 & 93.00 \\
\hline Blueberries & 47,272 & 0.61 & 93.61 \\
\hline Hay & 31,401 & 0.40 & 94.01 \\
\hline Others & 467,650 & 5.99 & 100.00 \\
\hline Total & $7,805,388$ & & \\
\hline
\end{tabular}

Table 6. Florida's leading agricultural exports to the world, 2007-2011 (USD 1,000s)

\begin{tabular}{|c|c|c|c|c|c|c|c|}
\hline Product & 2007 & 2008 & 2009 & 2010 & 2011 & $\begin{array}{c}\text { Average } \\
2007-2011\end{array}$ & $\begin{array}{c}\text { Cumulative } \\
\text { Share \% }\end{array}$ \\
\hline Edible fruits and nuts & 396,250 & 424,623 & 403,474 & 419,033 & 440,755 & 416,827 & 14.21 \\
\hline $\begin{array}{l}\text { Vegetable, fruit, or nut } \\
\text { preparations }\end{array}$ & 384,938 & 335,855 & 342,616 & 417,739 & 532,785 & 402,787 & 13.73 \\
\hline $\begin{array}{l}\text { Meat and edible meat } \\
\text { offal }\end{array}$ & 266,866 & 359,426 & 331,534 & 355,340 & 544,856 & 371,604 & 12.67 \\
\hline Edible vegetables & 287,741 & 291,205 & 277,061 & 255,386 & 297,907 & 281,860 & 9.61 \\
\hline $\begin{array}{l}\text { Live trees and other } \\
\text { plants }\end{array}$ & 113,449 & 116,984 & 106,560 & 107,391 & 105,698 & 110,016 & 3.75 \\
\hline $\begin{array}{l}\text { Total Agricultural } \\
\text { Exports }\end{array}$ & $2,536,426$ & $2,875,321$ & $2,724,107$ & $2,934,285$ & $3,598,203$ & $2,933,668$ & \\
\hline
\end{tabular}


Table 7. Florida agricultural exports to the world and Panama of selected commodities 2007-2011 (USD 1,000s)

\begin{tabular}{|c|c|c|c|c|c|c|c|c|c|c|c|c|c|}
\hline \multirow[t]{2}{*}{ Product } & \multirow{2}{*}{$\begin{array}{c}\text { Average } \\
\text { Florida } \\
\text { Exports } \\
2007- \\
2011\end{array}$} & \multicolumn{5}{|c|}{ Florida Exports to Panama } & \multirow{2}{*}{$\begin{array}{c}\begin{array}{c}\text { Florida } \\
\text { Exports } \\
\text { to } \\
\text { Panama }\end{array} \\
\%\end{array}$} & \multicolumn{5}{|c|}{ Panama Total Imports } & \multirow{2}{*}{$\begin{array}{c}\text { Panama } \\
\text { Import } \\
\text { Growth } \\
\text { Rate } \\
\%\end{array}$} \\
\hline & & 2007 & 2008 & 2009 & 2010 & 2011 & & 2007 & 2008 & 2009 & 2010 & 2011 & \\
\hline \multicolumn{14}{|l|}{$\begin{array}{l}\text { Edible fruits and } \\
\text { nuts: }\end{array}$} \\
\hline $\begin{array}{l}\text { Strawberries, } \\
\text { fresh }\end{array}$ & 45,006 & 54 & 130 & 91 & 157 & 111 & 0.24 & 418 & 419 & 361 & 522 & 635 & 51.87 \\
\hline $\begin{array}{l}\text { Oranges, } \\
\text { fresh }\end{array}$ & 12,750 & 12 & 32 & 12 & 27 & 43 & 0.20 & 190 & 337 & 536 & 522 & 649 & 242.21 \\
\hline Grapes, fresh & 12,706 & 202 & 14 & 168 & 84 & 152 & 0.98 & 6,866 & 7,307 & 8,045 & 8,683 & 10,095 & 47.00 \\
\hline $\begin{array}{l}\text { Walnuts, no } \\
\text { shell }\end{array}$ & 1,212 & 186 & 238 & 121 & 125 & 181 & 14.04 & 671 & 842 & 594 & 507 & 1,159 & 72.77 \\
\hline $\begin{array}{l}\text { Strawberries, } \\
\text { frozen }\end{array}$ & 383 & 54 & 130 & 91 & 157 & 111 & 28.36 & 163 & 257 & 327 & 500 & 621 & 281.63 \\
\hline \multicolumn{14}{|l|}{$\begin{array}{l}\text { Vegetable, } \\
\text { fruit, and nut } \\
\text { preparations: }\end{array}$} \\
\hline $\begin{array}{l}\text { Nut and } \\
\text { seed } \\
\text { preparations }\end{array}$ & 12,207 & 661 & 867 & 1,136 & 1,273 & 1,231 & 8.47 & 1,288 & 1,610 & 1,846 & 1,929 & 2,757 & 114.05 \\
\hline $\begin{array}{l}\text { Potatoes, } \\
\text { prepared }\end{array}$ & 4,223 & 415 & 443 & 232 & 118 & 268 & 6.99 & 10,617 & 10,240 & 12,476 & 12,631 & 15,451 & 45.61 \\
\hline \multicolumn{14}{|l|}{$\begin{array}{l}\text { Meat and edible } \\
\text { meat offal: }\end{array}$} \\
\hline $\begin{array}{l}\text { Fowls cuts, } \\
\text { frozen }\end{array}$ & 141,024 & 337 & 448 & 169 & 1,210 & 2,539 & 0.67 & 1,322 & 3,655 & 4,981 & 6,091 & 5,723 & 332.84 \\
\hline $\begin{array}{l}\text { Bovine } \\
\text { boneless, } \\
\text { frozen }\end{array}$ & 76,273 & 127 & 411 & 981 & 1,459 & 2,469 & 1.43 & 688 & 1,282 & 4,056 & 3,040 & 3,157 & 358.52 \\
\hline $\begin{array}{l}\text { Swine cuts, } \\
\text { frozen }\end{array}$ & 27,549 & 8 & 175 & 130 & 459 & 547 & 0.96 & 787 & 565 & 2,369 & 3,288 & 2,254 & 186.40 \\
\hline \multicolumn{14}{|l|}{$\begin{array}{l}\text { Edible } \\
\text { vegetables: }\end{array}$} \\
\hline $\begin{array}{l}\text { Kidney } \\
\text { beans, dried }\end{array}$ & 2,400 & 13 & 15 & 45 & 12 & 11 & 0.80 & 1,098 & 1,105 & 1,872 & 1,159 & 3,042 & 177.04 \\
\hline $\begin{array}{l}\text { Sweet corn, } \\
\text { frozen }\end{array}$ & 1,046 & 77 & 70 & 210 & 119 & 79 & 10.61 & 253 & 287 & 394 & 326 & 521 & 105.92 \\
\hline \multicolumn{14}{|l|}{$\begin{array}{l}\text { Live trees and } \\
\text { other plants: }\end{array}$} \\
\hline $\begin{array}{l}\text { Plants, live } \\
\text { (NES=not } \\
\text { elsewhere } \\
\text { specified) }\end{array}$ & 38,624 & - & 6 & 162 & 583 & 490 & 0.64 & 102 & 197 & 535 & 844 & 1,186 & 1063.88 \\
\hline
\end{tabular}


Table 8. Summary of selected market access conditions agreed upon in US-Panama FTA (metric tonnes [t])

\begin{tabular}{|c|c|c|c|}
\hline Category & Selected Commodities & Current Tariffs & Market Access \\
\hline Edible fruits and nuts & $\begin{array}{l}\text { Citrus and non-citrus } \\
\text { fresh fruits and nuts }\end{array}$ & $\begin{array}{l}\text { Applied tariffs } \\
(0-15 \%)\end{array}$ & $\begin{array}{l}\text { Tariffs/duties on fresh and frozen strawberries removed in } 10 \text { equal } \\
\text { annual stages beginning date of FTA, and duty free effective January } \\
1 \text { of year ten. } \\
\text { Immediate duty-free access for most US fresh citrus and non-citrus } \\
\text { fruits and nuts. } \\
\text { Shelled walnuts and fresh grapes continue to receive duty-free } \\
\text { treatment. }\end{array}$ \\
\hline $\begin{array}{l}\text { Vegetable, fruit, and nut } \\
\text { preparations }\end{array}$ & $\begin{array}{l}\text { Vegetables, fruit, and nut } \\
\text { products }\end{array}$ & $\begin{array}{l}\text { Applied rates } \\
(0-20 \%)\end{array}$ & $\begin{array}{l}\text { Immediate duty-free access through a } 3640 \mathrm{tTRQ} \text { at zero duty for } \\
\text { frozen French fries, growing at an annual } 4 \% \text { compounded rate, and } \\
\text { the over-quota tariff eliminated in } 5 \text { years. Tariffs on other prepared } \\
\text { potatoes, including hash browns, eliminated within } 10 \text { years. } \\
\text { Immediate duty-free access for peanuts and other nut and seed } \\
\text { products. Tariffs on most other nut and seed products eliminated } \\
\text { within } 10 \text { years. }\end{array}$ \\
\hline \multirow[t]{3}{*}{$\begin{array}{l}\text { Meat and edible meat } \\
\text { offal }\end{array}$} & Poultry meat & $\begin{array}{l}\text { Applied tariffs } \\
(0-260 \%)\end{array}$ & $\begin{array}{l}\text { Immediate duty-free access through a } 660 \text { t TRQ at zero duty for } \\
\text { chicken leg quarters, growing annually at annual } 10 \% \text { compounded } \\
\text { rate, with tariff phased out over } 18 \text { years and no tariff reductions for } \\
\text { first } 10 \text { years. Chicken leg quarters subject to safeguards at } 130 \% \text { of } \\
\text { the TRQ. } \\
\text { Tariffs eliminated immediately on frozen whole turkeys, most frozen } \\
\text { turkey cuts, and mechanically de-boned chicken. Tariffs on most other } \\
\text { poultry products eliminated within } 15 \text { years. }\end{array}$ \\
\hline & Bovine meat & $\begin{array}{l}\text { Applied tariffs } \\
(15-30 \%)\end{array}$ & $\begin{array}{l}\text { Immediate duty-free access for Prime and Choice beef cuts. } \\
\text { Tariffs on standard-quality beef eliminated within } 15 \text { years, with } \\
\text { no reductions during first } 5 \text { years. Standard-quality beef subject to } \\
\text { safeguards, with a trigger level of } 330 \mathrm{t} \text { and an annual compounded } \\
\text { trigger growth rate of } 10 \% \text {. }\end{array}$ \\
\hline & Swine meat & $\begin{array}{l}\text { Applied tariffs } \\
(60-70 \%)\end{array}$ & $\begin{array}{l}\text { Immediate duty-free access for fresh and frozen pork cuts through a } \\
\text { TRQ of 1,600 t, growing annually by } 6 \% \text { (compounded) or greater. } \\
\text { Some fresh and frozen pork cuts subject to safeguards at } 130 \% \text { of } \\
\text { TRQ. } \\
\text { Panama will phase out over-quota tariffs within } 15 \text { years, with no } \\
\text { reductions during an initial grace period. }\end{array}$ \\
\hline Edible vegetables & $\begin{array}{l}\text { Vegetables fresh, frozen, } \\
\text { dried, and preserved }\end{array}$ & $\begin{array}{l}\text { Applied tariffs } \\
(0-15 \%)\end{array}$ & $\begin{array}{l}\text { Immediate duty-free access through a } 795 \mathrm{tTRQ} \text { at zero duty for } \\
\text { kidney beans, growing at an annual } 6 \% \text { simple growth rate; the over } \\
\text { quota tariff will be eliminated in } 12 \text { years. } \\
\text { Tariffs on other edible vegetables, including onions, corn, celery, } \\
\text { beets, spinach, and potatoes, eliminated within } 15 \text { years. } \\
\text { Immediate duty-free access for fresh or chilled potatoes through a } \\
765 \text { t TRQ at zero duty, growing at } 2 \% \text { simple growth rate. After year } \\
15 \text {, in-quota quantity still will increase by } 2 \% \text {. }\end{array}$ \\
\hline $\begin{array}{l}\text { Live trees and other } \\
\text { plants }\end{array}$ & $\begin{array}{l}\text { Plants, live (NES=not } \\
\text { elsewhere specified) }\end{array}$ & $\begin{array}{l}\text { Applied rates } \\
(0-15 \%)\end{array}$ & $\begin{array}{l}\text { Live plants continue to receive duty-free treatment. Immediate duty- } \\
\text { free access for other live trees and other plants is granted. }\end{array}$ \\
\hline
\end{tabular}

